\title{
Rectal cancer in patients with hereditary nonpolyposis colorectal cancer: Surgical management and survival outcomes
}

\author{
Y Nancy You ${ }^{1 *}$, Devki S Saraiya ${ }^{2}$, Thuy M Vu', Jula Veerapong ${ }^{1}$, Patrick M Lynch², Miguel A Rodriguez-Bigas ${ }^{1}$ \\ From 14th Annual Meeting of the Collaborative Group of the Americas on Inherited Colorectal Cancer \\ Dallas, TX, USA. 12-13 October 2010
}

\section{Background}

Hereditary nonpolyposis colorectal cancer (HNPCC) is hallmarked by microsatellite instability. The prognosis of HNPCC-related colon cancer is well characterized, but little is known about rectal cancers. The aim of this study was to report the long-term outcomes of HNPCC-related rectal cancer where current-era multimodality therapy was utilized.

\section{Methods}

Patients referred to our institution for either primary or recurrent rectal cancer between 1992-2010 were identified based on following inclusion criteria: 1) pathogenic germline mutation in DNA mismatch repair genes (MMR; $n=19)$; 2) germline variants of uncertain significance but tumor studies suggestive of $\operatorname{MMR}(n=6) ; 3)$ suggestive tumor studies but negative germline testing $(n=5)$; and 4) suggestive tumor studies but no germline testing $(n=4)$. Patients were reviewed for clinical characteristics and treatments, and followed to death or last contact.

\section{Results}

Among the 34 patients, 21 (62\%) were female. The median age at diagnosis of rectal cancer was 40 (range: 20-72). In 28 patients (82\%), this was the index cancer leading to the diagnosis of HNPCC, and in 22 patients $(65 \%)$, this was their first malignancy. Only a minority satisfied Amsterdam I (21\%) or Amsterdam II (21\%) criteria, while nearly all (94\%) met the revised Bethesda criteria. Pathogenic mutations included MLH1 (15\%), MSH2 (32\%) and MSH6 (9\%). The

* Correspondence: ynyou@mdanderson.org

'Surgical Oncology, UT M.D. Anderson Cancer Center, Houston, TX 77030, USA Full list of author information is available at the end of the article majority (67\%) presented with locally advanced (T3/T4 and/or node positive, $\mathrm{n}=20$ ) or metastatic disease $(n=3)$, and $50 \%$ received neoadjuvant radiation with 5FU based chemotherapy. Final pathologic stages are as outlined below. Patients underwent proctectomy (65\%), total/near total coloproctectomy (21\%), transanal excision $(9 \%)$, and chemoradiation only (3\%). Multivisceral resection was required in 9 patients $(28 \%)$ and adjuvant therapy was given in 24 (71\%). After a median followup of 4.1 years, $94 \%$ were alive. Six patients developed local-regional $(n=3)$ or distant $(n=3)$ disease recurrence, and 5 underwent successful surgical salvage. Metachronous CRC was found in 4 patients (12\%) after a median of 8 years (range: $3.2-17$ ), and all were amenable to surgical resection. The estimated 5year freedom from recurrent or metachronous CRC was $76 \%$. The 5 -year overall survival was $93 \%$, which was preserved at 10 -years. Table 1 .

\section{Discussion}

Rectal cancer may present as the index cancer for HNPCC over a wide age range. Despite advanced stages at presentation, excellent long-term prognosis can be expected with aggressive multimodality therapy. Vigilant surveillance for recurrent or metachronous CRC should

Table 1

\begin{tabular}{llll}
\hline $\begin{array}{l}\text { Pathologic } \\
\text { Stage }\end{array}$ & $\begin{array}{l}\text { After neoadjuvant } \\
(\mathbf{n = 1 7 )}\end{array}$ & $\begin{array}{l}\text { No neoadjuvant } \\
(\mathbf{n}=\mathbf{1 7})\end{array}$ & $\begin{array}{l}\text { Total } \\
\mathbf{( n = 5 0 )}\end{array}$ \\
\hline 0 & $5(29 \%)$ & $2(12 \%)$ & $7(21 \%)$ \\
I & $2(12 \%)$ & $6(35 \%)$ & $8(24 \%)$ \\
II & $4(24 \%)$ & $5(29 \%)$ & $9(26 \%)$ \\
III & $5(29 \%)$ & $2(12 \%)$ & $7(21 \%)$ \\
IV & $1(6 \%)$ & & $1(3 \%)$ \\
Unknown & & $2(12 \%)$ & $2(5 \%)$ \\
\hline
\end{tabular}


be carried out over a prolonged time period to allow for repeat surgical salvage and preserved long-term survival.

\section{Author details}

${ }^{1}$ Surgical Oncology, UT M.D. Anderson Cancer Center, Houston, TX 77030, USA.

${ }^{2}$ Gastroenterology, Hepatology \& Nutrition, UT M.D. Anderson Cancer Center,

Houston, TX 77030, USA.

Published: 10 March 2011

doi:10.1186/1897-4287-9-S1-P41

Cite this article as: Nancy You et al:. Rectal cancer in patients with

hereditary nonpolyposis colorectal cancer: Surgical management and survival outcomes. Hereditary Cancer in Clinical Practice 2011 9(Suppl 1): P41.

Submit your next manuscript to BioMed Central and take full advantage of:

- Convenient online submission

- Thorough peer review

- No space constraints or color figure charges

- Immediate publication on acceptance

- Inclusion in PubMed, CAS, Scopus and Google Scholar

- Research which is freely available for redistribution 